\section{AGRIPPA, LEONARDO AND THE CODEX HUYGENS*}

$\mathrm{T}$ HE 1533 edition of Agrippa von Nettesheim's De occulta philosophia is an extended version of a treatise originally written in I5 10 under the same title. ${ }^{1}$ To the earlier framework the author added new ideas and new

* I am most grateful to the late Professor D. P. Walker and to Richard Simpson for the advice and help they gave me during the writing of this paper, which developed from a chapter in my Ph.D. thesis on Agrippa's use of Vitruvius III. I.

${ }^{1}$ Henricus Cornelius Agrippa ab Nettesheym, De occulta philosophia sive magia libri tres, Cologne I533, ed. K. A. Nowotny, Graz 1967 (hereafter Occ.phil).

The Occulta philosophia of I $5 \mathrm{IO}$ is preserved in Würzburg University Library, MS M. ch. q. 50. I used the proofs of an edition planned by Dr H. Meyer of the Warburg Institute in I930 (hereafter Meyer edn).

Journal of the Warburg and Courtauld Institutes, Volume 48, 1985 material mostly derived from the same sources that he had used in $1510 .^{2}$ But, as has been shown recently, ${ }^{3}$ a significant part of Agrippa's additions, and especially the ideas on man's knowledge of God and his ascent towards God, were taken from the De harmonia mundi of the Franciscan Francesco Giorgi, printed in 1525 , only eight years before the appearance of the final version of the De occulta philosophia. ${ }^{4}$ This note will show how, in developing the text of the De occulta philosophia, Agrippa linked Giorgi's ideas on microcosm with Leonardo da Vinci's studies on Vitruvian proportions, and suggests that to some extent his source for Leonardo's ideas was the same as that of the Codex Huygens.

${ }^{2}$ Cf. Nowotny op. cit. n. I above, pp. 41 5-56.

${ }^{3}$ Cf. P. Perrone Compagni, 'Una Fonte di Cornelio Agrippa. Il De harmonia mundi di Francesco Zorzi', Annali del istituto di filosofia (Firenze), rv, I 982, pp. 45-74.

${ }^{4}$ Francesco Giorgi, De harmonia mundi totius cantica tria, Venice I 525. For Giorgi (or Zorzi, Giorgio, Georgius) in general cf. C. Vasoli, Profezia e ragione, Naples r974, pp. 129-403. 
II

Agrippa's notion of magic in the De occulta philosophia of 1510 is based on the Aristotelian understanding of theoretical science divided into physics, mathematics and theology. ${ }^{5}$ In I 533 this scheme is rendered in terms of the neo-Platonic world order, defining magic as being concerned with a threefold world, elementary, celestial and intellectual. ${ }^{6}$ At the same time this fits into Pliny's definition of magic which is also used by Agrippa. ${ }^{7}$ The magician finds the power of the elementary world by means of medicine and natural philosophy, connects it mathematically and astrologically with the celestial world, and confirms all this with the help of ceremonial magic which according to the Aristotelian system of science is called theology. ${ }^{8}$ According to this pattern his treatise proceeds in three books dealing consecutively with physics, mathematics and theology by means of natural, celestial and ceremonial magic. Thus the magician ascends from the elementary world by means of physics, traverses the celestial spheres with mathematics and astrology, and finally achieves the true knowledge of God in the last step which is ceremonial magic. As the argument is developed in the second and third books, it becomes clear that the structure of man as a microcosm, containing in himself the elementary celestial and intellectual world, coincides both with the order of the universe and with the system of magic as given in the three books of the De occulta philosophia. It therefore plays an important part within the three stages of magic.

In Book II, chap. xxVII, microcosm and its geometrically and arithmetically fixed proportions $^{9}$ are to be regarded as a link both between the first and the final stage of magic as well as between the celestial and the intellectual world. ${ }^{10}$ In Book III, chap. xxxvi, the view of man as microcosm and image of God reveals the truth of God himself. ${ }^{11}$ In particular this

\footnotetext{
${ }^{5}$ Meyer edn, fols. $2^{\mathrm{v}}-4^{\mathrm{v}}$. Cf. Aristotle, Metaphysics, xı.7. (1064b).

6 Occ. phil., I. I., fol. I. For the order of the world described in terms of neo-Platonism cf. e.g. Giovanni Pico della Mirandola, Heptaplus, aliud prooemium, in id., De hominis dignitate. Heptaplus. De ente et uno e scritti vari, ed. E. Garin, Florence i 942 , p. 184 .

${ }^{7}$ Pliny, Naturalis historia, xxx. I.

8 Occ. phil., I. 2., fols $\mathrm{I}-3$.

9 Ibid., II.27., fols 160-70.

10 Cf. ibid., I. I., fol. I.

11 Ibid., iII.36., fols $284-89$.
}

interpretation of man as a microcosm is largely based on Francesco Giorgi's arguments as to how man can finally achieve the true knowledge of God. ${ }^{12}$ Quoting Giorgi Agrippa writes:

... nothing is found in man or in his composition in which something divine does not shine out; nor is there anything in God which is not displayed in man. Therefore, whoever knows himself, may know all things through himself. In particular he will know God in whose image he was made; he will know the world, the likeness of which he bears; he will know all creatures with which he has affinity; and what sustenance he can have and obtain from stones, plants, animals, heavens, from demons, angels and everything. ${ }^{13}$

Thus Giorgi's notion of man's spiritual destination in achieving the true knowledge of God has become a crucial part of Agrippa's ceremonial magic.

\section{III}

Giorgi's framework for his ideas on man's ascent to the view of the truth in God as given in the order of his three songs each divided into eight tones is largely based on an elaborate musical theory $^{14}$ whereas Agrippa's notion of magic generally does not follow this musical pattern. Only a few, mostly isolated, musical arguments remain. ${ }^{15}$ Quoting Giorgi he sometimes omits musical analogies ${ }^{16}$ and his chapter on the

${ }^{12}$ Cf. Giorgi, op. cit. n. 4 above, III., fols $7^{\mathrm{v}}, 3 \mathrm{I}^{\mathrm{v}}-32^{\mathrm{r}}$ and Occ. phil., II.36., fol. 286. Cf. Perrone Compagni, op. cit. n. 3 above, pp. $64-65$.

13 Occ. phil., III. 36 ., fol. 286 : ' . . nec reperitur aliquid in ho[m]i[n]e, non ulla dispositio, in quo no[n] fulgeat aliquid diuinitatis: nec quicq[uam] est in deo, quod ipsum non etia[m] repraesentet[ur] in homine. Quicunq[ue] igitur seipsum cognouerit, cognoscet in seipso omnia, cognoscet in primis deu[m], ad cui[us] imagine[m] factus est: cognoscet mundum, cuius simulacru[m] gerit: cognoscet creaturas omnes, cu[m] q[ui]bus symbolu[m] habet: \& $\mathrm{q}[\mathrm{ui}] \mathrm{d}$ fomenti à lapidibus, à plantis, $\mathrm{ab}$ animalibus, $a b$ elementis, à coelis, à daemonibus, ab angelis, \& ab unaquaq[ue] re habere \& impetrare possit ...' Cf. Giorgi, op. cit. n. 4 above, 11 , fols $56^{\mathrm{r}}$ and $7^{\mathrm{v}}$. Translations consulted are Henricus Cornelius Agrippa of Nettesheym, Three Books of Occult Philosophy, translated by J[ohn] F[rench], London 165 and Heinrich Cornelius Agrippa von Nettesheim, Magische Werke, 5 vols, Stuttgart I $855-56$.

${ }^{14}$ Giorgi, op. cit., I.5., fols $84^{\mathrm{r}}-98^{\mathrm{v}}$ and 1.6.2., fol. $100^{\mathrm{r}}$. Cf. J.-F. Maillard, 'Áspects musicaux du De harmonia mundi de George de Venise', Revue de musicologie, LVIII, 1972, pp. $162-72$.

15 Occ.phil., II.27., fol. 169 (cf. Giorgi, op. cit., I.6.3., fol. IO $^{\mathrm{r}}$ ) and II. $24-26$., fols $155-58$.

${ }^{16}$ Cf. e.g. Occ. phil., fol. 286, ll. 6-I I with Giorgi, op. cit., III. I. 7., fol. $7^{\mathrm{r}-\mathrm{v}}$. 
mathematically defined microcosm in the second book is only an incoherent mixture of heterogenous material taken from Giorgi, Leonardo da Vinci's proportional studies on Vitruvius and Pomponius Gauricus's De sculptura. ${ }^{17}$ There is no evidence that Agrippa used the Vitruvian text itself. He starts with some commonplaces on microcosm followed by the proportional canon of St Augustine, ${ }^{18}$ both taken from Giorgi. ${ }^{19} \mathrm{He}$ then describes six variations of Vitruvius's man in the circle and the square referring specifically to points made in Leonardo's well known study of this figure now in the Accademia in Venice (Pl. 45a). In discussing the drawing of a circle around the body Agrippa states:

Because if the hands are raised, and the feet and legs extended in such a way that the man's height standing is reduced by one fourteenth, the relative distance of the feet and of the lower abdomen forms an equilateral triangle; if the navel is taken as the centre the circumscribing circle touches the extremities of the hands and the feet. ${ }^{20}$

In sixteenth-century proportional studies Leonardo alone decreased the height of the Vitruvian man by one-fourteenth to fit into the circle. Another and longer passage again originates from Leonardo's own description on the Accademia drawing:

The chest measurement of a man taken under the armpits is half his length, the midpoint of which is the bottom of his chest: and from there up to the middle of his chest between both nipples, and from the middle of his chest to the crown of his head, is in each case a quarter of the height. Similarly, from the bottom of his chest to below the knees, and from thence to the bottom of the ankles is a quarter of a man. The width of the shoulders is the same. So is the

${ }^{17}$ E.g. Pomponius Gauricus, De sculptura, Florence I 504, fols $\mathrm{b}_{3}^{\mathrm{v}}-\mathrm{b}_{5}{ }^{\mathrm{v}}$ and Occ. Phil., fols $\mathrm{I} 67$ and $\mathrm{I} 69$.

18 Augustinus, De civitate Dei, xv.26., PL., 41, col. 472.

19 Occ. phil., fols $160-6$ 1. Cf. Giorgi, op. cit., min. I. I., fol. $2^{r}$ and I.6.3., fols $10 \mathrm{I}^{\mathrm{r}} \mathrm{-}^{\mathrm{v}}$.

20 Occ. phil., fol. I 65 : 'Quod si manibus sic eleuatis taliter pedes \& crura panda[n]tur, quo homo decimaquarta parte erectae staturae suae breuior sit, tunc pedum distantia ad imum pecten relata, aequilaterum triangulum faciet, \& centro in umbilic[o] posito circunductus circulus manuum pedumq[ue] extrema continget'.

For Leonardo's text cf. J. P. Richter, The Literary Works of Leonardo da Vinci, 2 vols, 2nd edn, London I 939, I, pp. 25556: 'Se tu apri ta[n] to le ga [m]be che tu cali da capo I/ I 4 di tua altezza e apri e alzi tanto le braccia che colle lunghe dita tu tochi la linia della som[m]ità del capo, sappi che 'I cie[n] tro delle stremità delle aperte me[m]bra fia il bellico e lo spatio che si truova infra le ga[m]be, fia, tria[n]golo equilatero'. length from the elbow to the end of the longest finger, and this is therefore called a cubit. Hence four cubits make a man's length, and one cubit the shoulderwidth; the width of the waist is one foot. Six palms make a cubit, four a foot, and four digits make a palm. The whole length of a man is twenty-four palms or six feet, or ninety-six digits. ${ }^{21}$

Additionally, he later gives some proportions not mentioned in Leonardo's text, but nevertheless taken from the drawing itself:

The diameter of the waist, the distance between the wrist and the inside of the elbow, the distance from the chest between the nipples to the upper lip or down to the navel, the space between the extreme ends of the upper bones of the chest which enclose the throat, the distance from the sole of the foot to the bottom of the calf, and from there to the centre of the knee joint, are all equal measurements, and are all one-seventh of the height. ${ }^{22}$

By marking lines showing the points of measurement on his drawing of the Vitruvian man, Leonardo makes it easy to trace these

21 Occ. phil., fol. 166 : 'Circuitus ho[m]i[n]is sub alis, medietate $[\mathrm{m}]$ suae co[n]tinet lo[n]gitudinis, cuius mediu[m] est in imo pectine: abinde uero sursum ad mediu[m] pectus inter utrasq[ue] mamillas \& à medio pectore in summu[m] uertice[m], utrobiq[ue] pars quarta: similiter ab imo pectine usq[ue] sub genua, \& inde ad extremos talos, pars ho[m]i[n] is quarta. Eade[m] est latitudo spatularu $[\mathrm{m}]$ ab uno extremo in alterum: eade $[\mathrm{m}]$ est longitudo à cubito in extremu[m] longioris digiti, ideoq[ue] hic cubitus dicit[ur]: hinc quatuor cubiti constituunt longitudine $[\mathrm{m}]$ hominis: latitudine[m] uero quae in spatulis est, cubitus unus: quae uero in cinctura est, pes unus, cubitum autem constituunt palmi sex: pedem uero quatuor, \& quatuor digiti palmum, totaq[ue] hominis lo[n]gitudo palmorum uigintiquatuor, pedem sex, digitorum sex \& nonaginta.' For Leonardo's text see Richter, loc. cit.: 'Vetruuio architecto mette nella sua opera d' architectura, che le misure dell' omo sono dalla natura distribuite in questo modo cioè che 4 diti $\mathrm{fa}[\mathrm{nno}]$ un palmo $\mathrm{e}$ 4 palmi fa[nno] uno piè, 6 palmi fa[nno] un cubito 4 cubiti fa[nno] uno uomo e 4 cubiti fa[nno] uno passo e 24 palmi $\mathrm{fa}[\mathrm{nno}]$ uno uomo e queste misure son ne' sua edifiti; ... dalle tette al di sopra del capo fia la quarta parte dell' omo: la maggiore larghezza delle spalle contiene in sé la quarta parte dell' omo, dal gomito alla punta della mano fia la quarta parte dell' omo: . . . dai di sotto del piè al di sotto del ginochio fia la quarta parte dell' omo; dal di sotto del ginochio al nascime[n] to del membro fia la quarta parte dell' omo....'The text is quoted according to the corrected reading of C. Pedretti, The Literary Works of Leonardo da Vinci. Commentary, 2 vols, Oxford I 977, I, p. 244.

22 Occ. phil., fols $166-67$ : 'Deniq[ue] cincturae diameter, \& quod à restricta manus usq[ue] in interiorem plicaturam cubiti spatium est: \& quod à pectore usq[ue] ad utrasq[ue] mamillas sursum ad suprema labra, siue deorsum usque ad umbilicum est, quodq[ue] est inter extrema ossium supremi pectoris gula $[\mathrm{m}]$ cingentiam [sic], \& quod à planta pedis ad fine $[\mathrm{m}]$ lacerti, \& exinde in mediam genu rotulam, omnes hae me[n]surae sibi coaequales sunt, \& septima[m] totius altitudinis constituu[n]t'. 
proportions. Furthermore, the first, the third and the fifth woodcut in the De occulta philosophia (Pl. $45^{\mathrm{C}-\mathrm{e})}$ repeat the position of the legs and the feet in Leonardo's study. ${ }^{23}$

\section{IV}

However, Agrippa's mixture of proportions by no means constitutes a coherent system. The quotations taken from Giorgi, from Leonardo's alterations of the Vitruvian proportions, a further, different, canon from Gauricus and a large number of very detailed proportional ratios which could have been taken both from Gauricus or from Leonardo ${ }^{24}$ have no intelligible relationship. Nor does this material fit into the few musical arguments taken from Giorgi. The incoherently integrated proportional studies function only as material to demonstrate the complexity of the mathematically organized microcosm which is the central metaphor for the second and intermediate state of magic. Agrippa's remarks on the six variations of Vitruvius's man in the circle and the square form a part of this wider discussion. $\mathrm{He}$ thus tries to fulfil his own requirement that everything is linked most powerfully by numbers and geometrical figures. ${ }^{25}$ But there is no attempt to achieve a general mathematical or a particular musical system to make all the different proportions fit.

Nevertheless, Agrippa's use of both Giorgi's ideas on microcosm and Leonardo's studies on proportion seems to demonstrate a significant shift in his notion of magic. Originally, in $\mathrm{I}_{5} \mathrm{IO}$, he had only worked out a magical system according to the Aristotelian understanding of theoretical science. Then, in the De incertitudine et vanitate scientiarum et artium, finished in ${ }^{1} 526$ and published in $153 \mathrm{I}$, he devoted eight chapters to magic describing its several aspects. ${ }^{26}$ Very much less systematic than the De occulta philosophia, these give a general survey of magic, natural and mathematical, devoted either to physical phenomena or to heavenly influences. Other chapters are concerned with

${ }^{23}$ Occ. phil., fols 16 1, 163 and 165 . Cf. Nowotny, op. cit n. I

${ }^{24}$ Cf. Gauricus, op. cit. n. I 7 above and Richter, op. cit. n. 20 above.

${ }_{25}$ Occ. phil., II. I-2., fols 99-10I and II.23., fol. I 54 .

${ }^{26}$ Henricus Cornelius Agrippa ab Nettesheym, De incerti-

tudine et vanitate scientiarum et artium, Antwerp 1530, fols $\mathrm{N}_{3}{ }^{\mathrm{v}}-\mathrm{P}_{3} \mathrm{v}$. the maleficent business of veneficious magic, goety, necromancy and the deceptive practice of magicians. Though he acknowledges that some considered the art of cabbala and theurgy as more legitimate, he finally retracts and condemns the art of magic in general and specifically as described in his De occulta philosophia of $15 \mathrm{IO}^{27}$

As a piece of rhetoric the De incertitudine et vanitate scientiarum et artium need not be taken too seriously. ${ }^{28}$ It provides, however, a contrast to Agrippa's notion of magic in 1533 when, following Giorgi, a coherent system of spiritual magic, having as its theological aim the knowledge of God, is developed. Agrippa presumably came to know Giorgi's De harmonia mundi in 1527 . In the same year he wrote to a friend complaining that the first two books of the De occulta philosophia were inadequate; the third book being 'totally crippled'. Therefore he promised to publish the whole work completely revised at some time. ${ }^{29}$ From this time on, therefore, he may have integrated the ideas from Giorgi's De harmonia mundi and especially the arguments on microcosm which he fitted into his magical system. The improved notion of magic now includes the old scheme of $15 \mathrm{IO}$, the application of the neo-Platonic order of the world and Giorgi's ideas on man as microcosm ascending from the lower world to the true knowledge of God. This new magical approach, depending largely on the utilization of Giorgi's ideas on microcosm and completed by material taken from Leonardo's studies on Vitruvian proportions, perhaps seemed to justify the reissuing of a book on magic which already had been retracted and condemned by the author himself in De incertitudine et vanitate scientiarum et artium.

\footnotetext{
27 Ibid., fol. $\mathrm{P}_{3}{ }^{\mathrm{r}-\mathrm{v}}$.

28 Cf. D. P. Walker, Spiritual and Demonic Magic. From Ficino to Campanella, London 1958, p. 90 and P. F. Grendler, Critics of the Italian World, Madison/Milwaukee/London I969, pp. 136-6I and passim.

${ }_{29}$ Epist. v. I4., Henricus Cornelius Agrippa ab Nettesheym, Opera , 2 vols, Lyons, Beringos Fratres (c. I6oo), II, p. 905: 'Caeterum quos postulas libros, aliqui illorum aliquando fuerunt penes me, sed jam non sunt: Qui vero penes vos circumferuntur libri adolescentiae meae de Occulta philosophia intitulati, horum priores duo in multis deficiunt: tertius totius mancus est; nec nisi scriptorum meorum epitoma quoddam continet. Sed ego totum opus, favente Domino, integrum recognitumque aliquando in lucem dabo'.
} 
Thirdly, it seems possible that Agrippa's illustration of the microcosmic man as the base for a pentagon ( $\mathrm{Pl} .45 \mathrm{~d}$ ) derives from the same source as fol. 7 of the Codex Huygens ${ }^{44}$ (Pl. $45 \mathrm{~b}$ ) since no other model is known to exist for this kind of drawing before $1533 .{ }^{45}$ In addition to the shared use of the pentagon, the general disposition of the arms and legs, and the use of the hands, feet and crown of the head as the vertices of the pentagon, are similar in the Agrippa woodcut and the Codex Huygens folio, while the details of the fingers and feet are the same in the Agrippa and Leonardo figures but different from the Codex Huygens. While the outer circumference of the pentagon is not given on the Agrippa woodcut, an inner pentagon forms the basis for a five pointed star. This star is circumscribed by the circle touching the man's extremities, and its horizontal diameter cuts the genitals of both the Agrippa and Codex Huygens figure, not the navel, as in the

${ }^{44}$ Occ. phil., fol. $6_{3}$ and Codex Huygens fol. 7, fig.cccc. Cf. Pedretti, loc. cit., 1, p. 65 .
Leonardo drawing. Furthermore, the text accompanying the woodcut refers to an equilateral triangle formed by the relation of the heels and the navel which is not shown in the illustration itself, although it appears on fol. 7 of the Codex Huygens. In the Accademia drawing text this triangle is described as bounded by the legs. These points suggest that the Agrippa woodcut may reflect an intermediate study between the Accademia drawing of Leonardo and fol. 7 in the Codex Huygens.

However, the extent to which Agrippa used Leonardo's material in a form which was later included in the Codex Huygens can only be clarified by further evidence on the compilation of this codex and its relationship to Leonardo's studies.

FRANK ZÖLLNER

Aby Warburg Fellow, Warburg Institute

45 Cf. J. Schouten, The Pentagram as a Medical Symbol, Nieuwkoop I968, pp. 52-53 and F. Secret/J.-P. Laurant, 'Pentagramme, pentalpha et pentacle à la Renaissance', Revue de l'histoire des religions, CLXXX, I97 I, pp. I I 3-33. 